\title{
AUGUSTINE'S USE OF NEOPLATONISM IN CONFESSIONS VII: A RESPONSE TO PETER KING
}

\author{
Michael Gorman
}

I want to begin by thanking Peter King for his rich paper. King sees that there is a difference between looking at things our way and looking at things Augustine's way, and he recognizes the importance of trying to look at things Augustine's way. He is right to insist on this because we ought to care about the truth of history, but he is right for another reason as well. If we don't try to get inside the thought-worlds of the authors of old books, we end up using those books merely as occasions for saying what we today consider "interesting." When we do that, we miss a chance to learn from those books, and from their authors - some of whom just might have been smarter than we are.

King takes as his main text the "books of the Platonists" passage in Confessions VII. The problem he is interested in, and how he deals with it, can be summed up in the following way. Augustine tells us that he found the Trinity in the Neoplatonists but not the Incarnation, and he blames the Neoplatonists for having missed the latter while praising them for having grasped the former. His use of passages from the Bible to summarize what the Neoplatonists did and did not say make it hard to figure out precisely what he is thinking of, but at first glance, it's hard to avoid the conclusion that Augustine is a poor historian of philosophy. Attributing a grasp of Trinitarian doctrine to the Neoplatonists looks like little more than wishful thinking, and blaming them for missing the Incarnation seems like holding them to a set of standards that it makes no sense to apply. But all these difficulties come from failing to look at Neoplatonism as Augustine would have looked at it. If we look at it as he would have, his claims will make much more sense to us: we will be able to see what is going on philosophically in Confessions VII, and we will be able to see that Augustine is doing more than assessing the Neoplatonists according to an external dogmatic scorecard.

In my commentary I will address the following topics: (i) what it means to speak of the "philosophically" interesting points in Augustine; (ii) whether Confessions VII is really about the Michael Gorman - Augustine's Use of Neoplatonism 
Trinity; (iii) Augustine's intentions in Confessions VII; (iv) King's "hypostatic interpretation"; (v) Christology.

\section{I: GETTING AT THE PHILOSOPHICAL POINTS IN AUGUSTINE}

King raises the question of whether Augustine is leaving us under-informed about what is of philosophical interest and instead telling us only about—well, about what? In his introduction, he says that Augustine discusses the works of the Neoplatonists "as though all that mattered were their stance vis-à-vis Christian dogma." At the end of the section "Intermediaries and Mediators," he distinguishes something that is "a mere test for dogmatic orthodoxy" from something that "rests on a solid philosophical basis."

King means that Augustine does not tell us in any detail about the substantive thinking he encountered in the Neoplatonists and instead tells us only which Neoplatonic teachings correspond to Christian doctrine and which do not. But I have a worry about how King expresses this point. He contrasts dogma and philosophy (where "philosophy" means serious intellectual content), and sometimes he suggests that Christian dogma is a kind of language for expressing or clothing truths arrived at independently of faith. This might give the impression that dogma is not a serious intellectual matter: on the one hand, there's serious intellectual content, and on the other hand, there are certain verbal expressions that bishops try to get other people to repeat. But it would be very un-Augustinian to think in this way. The teachings of scripture and the Church are for Augustine of the greatest intellectual importance. Dogma for Augustine is not primarily a question of using certain words or formulas, but of getting the ideas right — as we can see, for example, from his analyses of things said by Pelagius and Celestius in his admittedly much later On the Grace of Christ and on Original Sin. So while I doubt there is a problem here in the substance of what King intends, I think the point needs to be made a bit more carefully.

\section{II: IS CONFESSIONS VII REALLY TALKING ABOUT THE TRINITY?}

Now I want to look more carefully at the "books of the Platonists" passage. King sees this as Augustine's recounting of how he found in those books adequate views on the Trinity but inadequate views on the Incarnation — or, as King also expresses the same distinction, using

Michael Gorman - Augustine's Use of Neoplatonism 
different and perhaps somewhat loose language, adequate views on metaphysics but inadequate views on ethics. But if thinking about the Trinity means thinking about three divine persons or hypostases, then there is serious reason to doubt that Augustine is thinking about the Trinity in this passage.

Augustine says he found the Neoplatonists to be saying, in the words of Jn 1.4, that "What was made in Him was life, and life was the light of men." On King's analysis, Augustine means that the Neoplatonists were talking about the Holy Spirit. Necessarily this is speculation on King's part, because Augustine does not paraphrase or gloss the verse in any way. In my opinion, the speculation is quite a stretch and indeed not likely to be correct. I do not think I can demonstrate this conclusively, but here are two considerations. First, in his First Tractate on John, Augustine discusses the verse in detail, parsing it rather differently from the way in which King seems to be parsing it, and he says nothing about the Holy Spirit — the reference to "life" is taken to be a reference to the way in which things pre-exist in the divine Word. Second, considering his writings more broadly now, Augustine does not - as far as I know-associate the word "life" with the Spirit in any special way. His normal words for the third person of the Trinity are "Holy Spirit" (of course), "Love," and "Gift." In De Trinitate book I, chapter 6 and elsewhere, Augustine says that the Son is Eternal Life, which is not too surprising considering that Jesus says in the Fourth Gospel that he is the Way, the Truth, and the Life. In De

Trinitate 15, chapters 5-6, "life" seems to be treated as a divine property that we should attribute to the Godhead as a whole without respect of persons.

The fact that I have just given an example of "life" language being specific to the Son, and then an example of "life" language being generally applicable to God, shows that Augustine can be pretty flexible. Perhaps somewhere in his writings he does identify "life" with the Holy Spirit. But he does not do this explicitly in Confessions VII, and I would feel more comfortable with King's reading of Confessions VII if we had a passage from somewhere else in Augustine's corpus that made the identification explicitly—even better, one that made the identification in connection with Jn 1.4.

Turning now to the Father, it seems more than fair to read some of the appearances of the word "God" in the early verses of John as references to the Father, and more than fair to take Augustine to be reading them that way. "The Word was with God"- - the Word wasn't with Michael Gorman - Augustine's Use of Neoplatonism 
himself, so here "God" must mean the Father. To this extent, the passage is indeed Trinitarian or anyway incipiently Trinitarian: it refers to what will come to be spoken of as two different divine persons. But the emphasis is not on duality of person, on the difference between the Father and the Son, but instead on the Son's equality with the Father. What the references to the Father do is help establish the Son's divinity.

This brings me to my main point in this section. Augustine's purpose in the "books of the Platonists" passage is not to discuss the Trinity and the Incarnation but instead to discuss the Divinity of the Word and the Incarnation. He aims to draw a contrast not between success in grasping the three persons and failure to grasp that the second person became incarnate, but instead between success in grasping that the second person is divine and failure to grasp that the second person became incarnate. The whole passage, in other words, is Christological (or "ethical") - the Father is brought in only to serve the purpose of discussing the Son, and there is no discussion of the Spirit at all.

This Christological way of reading the passage is supported, I believe, by a look at the overall flow of Book VII. Augustine's problems at the outset of the book are materialism and evil. He devotes the first eight chapters to these (along with a discussion of astrology). In chapter 9, he tells us about his encounter with the books of the Platonists. In chapter 10, he tells us that he began his intellectual investigations anew, having benefited from this reading: "Being thus admonished to return to myself, under your leadership I entered into my inmost being. What did he learn? In chapters 10-11, we find that he overcame his materialism. In chapters 1216, we find that he came to a better understanding of evil. Finally, in chapters 17-21, we learn that he still faced deep problems - he still needed to arrive at a proper understanding of Christ and to humbly accept Christ's mediatorship. The structure and punch-line of the chapter, then, is Christological/ethical; the Trinity as such is not at issue.

It seems unlikely, then, that in Confessions VII Augustine is telling us that the Neoplatonists knew about the triune God. That's not to say, of course, that Augustine didn't think there was a kind of triadism at work in the Neoplatonists. He discusses it, for example, in De civitate Dei book 10, c. 23. So King's plan to reconstruct Augustine's way of reading the Neoplatonists is still an important one. It's just that it's not clear how doing so is related to the interpretation of Confessions VII.

Michael Gorman - Augustine's Use of Neoplatonism 


\section{III: AUGUSTINE'S INTENTIONS IN CONFESSIONS VII}

If my worries in the last section of this commentary are correct, then it is clear enough why the "books of the Platonists" passage does not give us the Neoplatonic arguments for the three divine persons: it isn't about the three divine persons. But to say this is not fully to address King's concerns. Aside from the already-mentioned fact that we can still ask about Augustine's understanding of the Neoplatonic triad, there is also the question of why Augustine does not explain the Neoplatonists' arguments but instead quotes the Bible. If Augustine's concerns in Book VII are immateriality and evil, on the one hand, and Christ, on the other hand, then why then does he not spell out the Neoplatonists' arguments on immateriality, evil, and noûs? Isn't it still the case that citing Scripture, instead of the books of the Platonists themselves, "undercuts" the "philosophical significance" of Augustine's reading of the Platonists' books, as King says, that it serves his purpose "oddly"?

It depends on what his purpose is. If his purpose is intellectual autobiography, then it certainly would be better for him to give us the details. But consider how, in Confessions II.3.5, while discussing his career as a student, Augustine interrupts himself to say: "To whom do I tell these things? Not to you, my God, but before you I tell them to my own kind, to mankind, or to whatever small part of it may come upon these books of mine. Why do I tell these things? It is that I myself and whoever else reads them may realize from what great depths we must cry unto you." "iii This might be interpreted narrowly, as concerning only Augustine's intentions in telling us about his career as a student, but it seems more natural to suppose that it bears on Augustine's overall intentions in the Confessions. In the Retractationes he says, "The thirteen books of my Confessions, concerning both my evil and my good, give praise to the just and good God and arouse man's mind and feeling towards him.,

Augustine's main concern in the Confessions, then, is what we might call spiritual or pastoral or homiletic. I certainly do not mean that intellectual matters are foreign to such concern or that we are mistaken when we look for them. My point is only that Augustine's discussion of intellectual topics - "philosophical" topics as King often styles them-is subordinated to this other goal. With that in mind, perhaps it is not so surprising after all that Augustine proceeds as he does. If his goal is to promote conversion to Christianity, and to Michael Gorman - Augustine's Use of Neoplatonism 
deepen the faith of those who are already Christian, then we would not expect him to linger on the strengths of pagan philosophy but on its weaknesses. And if, in his view, the key to conversion is humility, then we would expect him to dwell in particular on that weakness within pagan philosophy that has to do with humility, that is, with its inability to see that the immaterial infinite Word could become flesh. " So Augustine's reticence about the Neoplatonists, although frustrating for us, is altogether in accord with his own intentions, and his use of Scripture is in accord with those intentions as well, because it presents the real issue - becoming Christian — in Christian terms.

\section{IV: TRINITARIANISM AND NEOPLATONISM}

Although I have cast doubt on the idea that Confessions VII is about the Trinity, I have not in the least cast doubt on the value of trying to understand how Augustine understands the relationship between the three hypostases of the Neoplatonists and the three Persons of the Trinity. This is where King's reconstruction of Augustine's "hypostatic" way of reading the Neoplatonists comes in. In this section I will not be disagreeing with King but instead simply pointing out two things that need to be clearer.

First, King has a contrast in mind according to which thinking in terms of a triad of some sort or other is not sufficient for thinking in Trinitarian terms. And this is quite rightshamrocks have three leaves, but that doesn't make botany Trinitarian. But what needs to be spelled out more is what (so to speak) the specific difference of Trinitarianism is supposed to be. In his introduction, King seems to imply that a triadic theory is Trinitarian only if it sees God as creating the world freely and with love for each creature. In the following section, by contrast, King says that "Augustine reads Plotinus as proving that the divine is necessarily and essentially triune-indeed trinitarian," but this time King is not talking about creation but instead about how to understand the three hypostases: in particular, whether we can understand the differences among them in a way that does not prevent us from seeing them as somehow all being one God.

Since it is the question of hypostases, and not the question of creation, that King focuses on, I feel pretty sure that the latter way of distinguishing triadism from Trinitarianism is what he has in mind. And that leads me to my second point. In the section titled "The 'Hypostatic' Interpretation," King discusses how Augustine might have understood Plotinus's triad. King's Michael Gorman - Augustine's Use of Neoplatonism 
idea is that, however clear it might seem to $u$ s that Plotinus's three hypostases couldn't possibly correspond to the Father, Son, and Holy Spirit, the way Augustine would have understood them makes the identification pretty plausible. King's idea appears to be that from a non-Augustinian perspective, the Neoplatonic hypostases look too distinct from one another to belong to one God, but that from Augustine's perspective, they do not look so distinct. What needs a lot more spelling out, in my view, is precisely how Augustine would have understood these hypostases so as to leave them less distinct. After sketching a sense of "hypostasis" which corresponds closely enough to an Aristotelian primary substance, King says, "Augustine would have understood Plotinus in Enneads 5.1 to be talking about (admittedly divine) individual realities." But are not Aristotelian primary substances still too distinct from one another to be the three Trinitarian persons? It would take a good deal more work in Trinitarian theology to explain how this approach would avoid tri-theism. (King further comments on the words "persona" and "prosôpon," but I do not see how what he says helps.) It is because of just such problems, of course, that Trinitarian theology ends up being so very complicated..

To bring this section to a close, we need to see more clearly what the difference is between Neoplatonic hypostases as non-Augustinians (are tempted to) understand them and Neoplatonic hypostases as Augustine understands them. Beyond that, if necessary, we need to see what more is needed to arrive at a fitting understanding of Father, Son, and Holy Spirit. My suspicion is that, for Augustine, there turns out to be a larger gap between Christianity and Neoplatonism than King seems to hold out for.

\section{V: CHRISTOLOGY}

Now let us turn to Christology, which King treats as an ethical issue insofar as it has to do with salvation. He gives us a speculative reconstruction according to which Augustine sees the Christian doctrine of the Incarnation as a response to the problems internal to Neoplatonism. I find this a very interesting proposal, and I wish I could say more about it. It might not be the only way Augustine thinks of the need for redemption, but it could be one way, a way that would be particularly well-suited to presenting Christianity to certain people, and furthermore a way that might have corresponded most closely to his own thinking in the 380s. The relationship

Michael Gorman - Augustine's Use of Neoplatonism 
between Neoplatonists and Christians on the issue of salvation is, all on its own, a very good topic of inquiry.

I do have one question. King seems to reject the idea that Christ for Augustine is the mediator in virtue of being halfway between the divine and the human. But it seems that, at least sometimes, this is just what Augustine thinks mediatorship involves. In On the Grace of Christ and on Original Sin Book II, Chapter 33, Augustine says that Christ is the mediator because he is, qua human, less than the Father, and because he is, qua sinless, greater than other humans. This seems to be a theory of mediatorship according to which the mediator precisely is someone who holds a middle place. Now that work of Augustine's is from the year 418, quite a bit later than the Confessions. Perhaps Augustine's views changed over the years. At any rate it seems clear that more detailed work needs to be done to figure out Augustine's views on the how of Christ's mediatorship.

In this brief commentary I have tried to touch on a few ways in which one might pursue the very interesting and worthwhile project of understanding Augustine's views on Neoplatonism and its relation to the Christian faith. This is a very challenging task, in part because Augustine's views change, and in part because his intentions sometimes lead him to write in a way that impedes our efforts to satisfy our legitimate curiosity. All the more reason to pay close attention to exactly what Augustine was thinking, and for an excellent start on this we can all think Peter King. ${ }^{\text {vi }}$

\section{NOTES}

${ }^{\text {i }}$ Except where noted, I use King's translation of Augustine (and of Augustine's quotations) as found in King's paper in this volume.

ii Translation by John K. Ryan in The Confessions of St. Augustine (New York: Image, 1960).

iii Ryan's translation.

iv "Confessionum mearum libri tredecim et de malis et de bonis meis deum laudant iustum et bonum atque in eum excitant humanum intellectum et affectum" (Retractationes II.6; Michael Gorman - Augustine's Use of Neoplatonism 
text as found in Sancti Augustini Confessionum libri XIII, Corpus Christianorum Series Latina vol. 27, ed. Lucas Verheijen after M. Skutella [Turnholt: Brepols, 1981], p. xxxi), translation mine.

${ }^{\mathrm{v}}$ For more on humility and Neoplatonism in Augustine, see Brian E. Daley, "A Humble Mediator: The Distinctive Elements of St. Augustine's Christology," Word and Spirit 9 (1987): 100-117.

${ }^{\mathrm{vi}}$ A slightly different version of this paper was presented as a commentary on Peter King's “Augustine's Encounter With Neoplatonism” at the Sixth Henle Conference in the History of Philosophy at St. Louis University. I am grateful for audience comments and for discussions with Brian Daley, Anne-Marie Gorman, and David Williams.

Michael Gorman - Augustine's Use of Neoplatonism 